\title{
Analisis Peran Kepala Sekolah Dalam Menerapkan Kedisiplinan Guru Di Mi Ma'arif Garongan Kulonprogo
}

\author{
Mastura Abdullah \& Sukati \\ Prodi PGMI Universitas Alma Ata \\ sukati79@gmail.com
}

\begin{abstract}
Abstrak
Penelitian ini dilatar belakangi oleh kedisiplinan guru datang kantor tidak sesuai jam kantor, masih maraknya kelas kosong disaat jam pelajaran, kedisiplinan menjadi titik permasalahannya. Kedisiplinan seorang guru sangat mempengaruhi kedisiplinan siswa, jika kedisiplinan guru baik akan berdampak positif pada siswa begitupun sebaliknya. Disamping itu ada sosok figur yang menjadi panutan atau pemimpin yang berperan penting dalam dunia sekolah yaitu kepala sekolah. Oleh sebab itu penelitian ini bertujuan untuk mengetahui bagaimana peran kepala sekolah dalam menerapkan kedisiplinan guru di sekolah MI Ma'arif Garongan, Kulonprogo Yogyakarta. Dan untuk mengetahui faktor penghambat dan pendukung dalam menerapkan kedisiplinan guru di MI Ma'arif Garongan Kulonprogo Yogyakarta.

Jenis penelitian ini merupakan jenis penelitian kualitatif dengan teknik pengumpulan data menggunakan teknik observasi, wawancara dan dokumentasi.

Anaisis Hasil penelitian menunjukkan bahwa: 1) Peran Kepala sekolah dalam menerapkan kedisiplinan guru di MI Ma'arif Garongan Kulonprogo Yogyakarta. adalah: Kepala sekolah berperan sebagai pelaksana, perencana, seorang ahli, pelindung, Pemegang tanggung jawab, sebagai pencipta, dan sebagai wasit. 2) faktor penghambat serta solusi kepala sekolah dalam menerapkan kedisiplinan guru di MI Ma'arif Garongan Kulonprogo Yogyakarta adalah faktor keadaan keluarga, keadaan sekolah, keadaan masyarakat. sedangkan solusi kepala sekolah dalam menerapkan kedisiplinan guru di MI Ma'arif Garongan adalah melakukan musyawarah bersama untuk mencari jalan keluar.
\end{abstract}

Kata Kunci: Kedisiplinan guru, peran kepala sekolah

\begin{abstract}
This research was motivated by the discipline of teachers coming to the office not according to office hours, still the prevalence of vacant classes during class hours, discipline became the point of the problem. The discipline of a teacher greatly affects the discipline of students, if good teacher discipline will have a positive impact on students and vice versa. Besides that there is a figure who becomes a role model or leader who plays an important role in the school world, namely the principal. Therefore this study aims to find out how the role of school principals in implementing teacher discipline in MI Ma'arif Garongan school, Kulonprogo, Yogyakarta. And to find out the inhibiting and supporting factors in implementing teacher discipline at MI Ma' arif Garongan Kulonprogo Yogyakarta. This type of research is a type of qualitative research with data collection techniques using observation, interview and documentation techniques. Anaisis The results of the study show that: 1) The role of the Principal in implementing teacher discipline in MI Ma'arif Garongan Kulonprogo Yogyakarta. are: Principals act as executors, planners, experts,
\end{abstract}


protectors, holders of responsibility, as creators, and as referees. 2) inhibiting factors and the solution of principals in implementing teacher discipline at MI Ma'arif Garongan Kulonprogo Yogyakarta are factors in family conditions, school conditions, community conditions. while the headmaster's solution in implementing teacher discipline in MI Ma'arif Garongan is to hold collective meetings to find a way out.

\section{Keywords: Teacher discipline, the role of the principal}

\section{PENDAHULUAN}

Pendidikan memiliki peran yang sangat strategis, karena pendidikan menentukan kualitas sumber daya manusia. Peran strategi pendidikan tersebut melibatkan tenaga kependidikan. Tenaga kependidikan mempunyai peran dalam pembentukan pengetahuan, keterampilan dan karaktek peserta didik. Oleh karena itu, tenaga kependidikan yang profesional akan melaksanakan tugasnya secara profesional, sehingga menghasilkan kualitas peserta didik yang bermutu. Ketercapaian tujuan sangat tergantung pada kecakapan dan kebijaksanaan kepala sekolah sebagai pemimpin. Kepala sekolah merupakan pejabat profesional yang ada dalam organisasi sekolah, yang bertugas untuk mengatur semua sumber daya sekolah dan bekerja sama dengan guru-guru, staf, dan pegawai lainnya dalam mendidik peserta didik untuk mencapai tujuan pendidikan. ${ }^{1}$

Kepala sekolah merupakan pemimpin pendidikan ditingkat sekolah. Kepala sekolah penanggung jawab atas terlaksananya proses pendidikan disekolah dalam mencapai tujuannnya. Kepala sekolah adalah pemimpin yang mempunyai peranan yang sangat penting dalam meningkatkan mutu pendidikan sekolah. ${ }^{2}$

Salah satu kekuatan efektif yang sangat menentukan keberhasilan sekolah atau lembaga pendidikan dalam mencapai tujuannya adalah kepemimpinan kepala sekolah. Kepemimpinan kepala sekolah juga menjadi penentu utama terjadinya proses dinamisasi sekolah. Efektifitas

${ }^{1}$ Euis Karwati dan Donni Juni Priansa. Kinerja dan Profesionalisme Kepala Sekolah, (Bandung : Alfabeta, 2013) hlm.82

${ }^{2}$ Wahjosumidjo.Kepemimpinan Kepala Sekolah. (Jakarta:Rajawali Pers.1995) hlm.366 kepemimpinan pendidikan tidak dapat lepas dari beberapa aspek yang membangun terjadinya efektifitas kepemimpinan sehingga mutu pendidikan akan dapat dicapai. Kegagalan dan keberhasilan sekolah banyak ditentukan oleh kepala sekolah, karena kepala sekolah merupakan pengendali dan penentu arah yang hendak ditempuh oleh sekolah menuju tujuannnya. ${ }^{3}$

Sekolah yang disiplin akan melahirkan kondisi yang baik, nyaman, tentram dan teratur. Istilah disiplin merupan saduran dari Bahasa Inggris yaitu "dicipline" yang berarti pelatihan pola pikir, karakter dan upaya pengembangan dan pengendalian pola pikir dan karakter yang dimaksudkan untuk menciptakan kepatuhan dan ketaatan kepada perilaku yang tertib dan teratur. ${ }^{4}$ Disiplin merupakan kepatuhan untuk menghormati dan dilaksanakan suatu sistem yang mengharuskan orang untuk tunduk kepada keputusan perintah atau pertaturan yang berlaku. ${ }^{5}$ Kemudian disiplin juga merupakan kesadaran dan kesediaan seseorang mentaati semua peraturan dan norma-norma yang berlaku. $^{6}$

Masalah kedisplinan guru menjadi sangat berarti bagi kemajuan sekolah. Disekolah yang tertib akan selalu mencipatakan proses pembelajaran yang baik. Sebaliknya, disekolah yang tidak tertib kondisinya akan jauh berbeda

${ }^{3}$ Enco Mulyasa, Menjadi Kepala Sekolah Profesional.(Bandung: PT Remaja Rosda Karya, 2011) hlm.158

${ }^{4}$ Ratna, Sri dan Murtini, Dinamika Kelompok. (Jakarta: LAN, 2006) hlm.32

${ }^{5}$ Lembaga Ketahan Nasional, Disiplin Nasional, (Jakarta: Balai Pustaka, 1997) hlm.12

${ }^{6}$ Abdurrahmat Fathoni. Manajemen Sumber Daya Manusia. (Jakarta : Rineka Cipta, 2006) hlm.126 
dari sekolah yang berdisiplin. Pelanggaranpelanggaran yang terjadi sudah dianggap barang biasa dan untuk memperbaiki keadaan yang demikian tidaklah mudah. Hal yang diperlukan kerja keras dari berbagai pihak untuk mengubahnya, terutama kepala sekolah yang sangat berperan sekali dalam mendisiplinkan guru.

Para guru sebagai garda terdepan pendidikan negeri ini tentu harus bekerja keras untuk menghasilkan dan membawa anak didik kepada gerbang kesuksesan dan keberhasilan, sehingga bisa mengangkat harkat dan martabat bangsa serta bisa membangun negeri ini dengan baik. Guru tentu tidak akan berhasil dengan baik jika perangkat pendidikan dan segala prantara pendidikan yang akan mengarahkannya dalam mendidik anak tidak tersedia atau tidak berfungsi dengan baik. Karena itu, sistem yang baik, kurikulum yang tepat, suasana pendidikan yang kondusif, gaji yang memadai, serta kepala sekolah yang memimpin dengan bijak dan berorientasi kemajuan, tentu saja sangat diharapkan oleh para pendidik. ${ }^{7}$

Bila kepala sekolah mempunyai keahlian yang lengkap sebagai pemimpin sebuah institusi sekolah; bila guru mempunyai keahlian memadai sesuai dengan bidangnya masingmasing serta mempunyai keterampilan mendidik dan mengajar yang baik serta mempunyai sifat mendidik yang sudah berakar dari dalam gerak langkahnya; bila anak didik bisa belajar dan mampu menyerap segala materi pendidikan yang diajarkan sekolah dan mampu beraktivitas dengan layak, lancar, dan mencerminkan jiwa pendidikan: maka segala apa yang menjadi keinginan semua orang terhadap insan pendidikan akan terwujud. Dan hasilnya adalah dengan terampilnya generasi muda masa depan bangsa sehingga mampu membangun negeri ini dengan baik dan maju. ${ }^{8}$

\footnotetext{
${ }^{7}$ Abdul Munir. Menjadi Kepala Sekolah Efektif. (Yogyakarta: Ar-Ruzz Media,2014) hlm.6 ${ }^{8}$ Ibid...,hlm.7
}

\section{METODE PENELITIAN}

Metode penelitian merupakan prosedur atau cara untuk mengetahui sesuatu, yang mempunyai langkah-langkah sistematis. ${ }^{9}$

Penelitian ini merupakan jenis penelitian kualitatif, penelitian kualitatif adalah penelitian yang menghasilkan produser analisis yang tidak menggunakan produser analisis statistik atau cara kuantifikasi lainnya. Jelas bahwa pengertian ini mempertentangkan penelitian kualitatif dengan penelitian yang bernuansa kuantitatif yaitu dengan menonjolkan bahwa usaha kuantifikasi apapun tidak perlu digunakan pada penelitian kualitatif. ${ }^{10}$

Dalam penelitian ini menggunakan metode penelitian kualitatif, yaitu metode penelitian naturalisttik karena penelitiaannya dilakukan pada kondisi ilmiah (naturalsetting) disebut juga sebagai metode etnographi karena pada awalnya metode ini digunakan sebagai metode kualitatif, karena data yang terkumpul dan analisisnya kualitatif. ${ }^{11}$

Teknik pengumpulan data dengan mengunakan metode observasi, wawancara, dokumentasi dan catatan lapangan. Sedangkan analisis data menggunakan beberapa metode menurut Lexy yaitu telaah data, reduksi data, dan menarik kesimpulan ${ }^{12}$

\section{HASIL DAN PEMBAHASAN \\ Peran Kepala Sekolah dalam Menerapkan Kedisipinan Guru di MI Ma'arif Garongan Kulonprogo}

Salah satu cara mengukur kemampuan kepala sekolah dalam memimpin sekolahnya adalah dalam mendisiplinkan guru. Bahkan berhasil tidaknya suatu sekolah dalam persoalan disiplin sangat tergantung kepada kepala

${ }^{9}$ Husain Usman, Metode penlitian sosial, (Jakarta : Bumi Aksara, 1996),hlm.24

${ }^{10}$ Lexi J.Moleong,M.A. Metodelogi penelitian kualitatif, (Bandung: PT Remaja Rosdakarya.2010), hlm.6

${ }^{11}$ Sugiyono.Metodelogi Kuantitatif Kualitatif dan $R \& D$, (Bandung : Alfabeta, 2009), hlm.2

${ }^{12}$ Lexi J.Moleong,M.A. Metodelogi penelitian..., hlm. 248

LITERASI, Volume X, No. 2 2019|101 
sekolah sebagai orang bertanggung jawab dalam lembaga pendidikan tersebut. Oleh karenanya, disiplin dapat digunakan sebagai barometernya dan kepala sekolah memiliki andil yang besar dalam menjalankan dan melaksanakan dengan sebaik-baiknya.

Berdasarkan hasil penelitian telah dilakukan di MI M'arif Garongan tentang peran kepala sekolah dalam mendisiplinkan guru di MI M'arif Garongan, temuan yang dikemukakan pada bagian ini berdasarkan paparan data yang diperoleh dilapangan. Penyajian temuan tersebut untuk menjawab pertanyaan penelitian sebagaimana yang telah ditetapkan pada Bab Pendahuluan. Temuan-temuan tersebut sesuai yang ada yakni sebagi berikut: kepala sekolah sebagai pelaksana, perencana, seorang ahli, pelindung, Pemegang tanggung jawab, sebagai pencipta, sebagai wasit, harus dapat diupayakan agar guru dan semua tenaga kependidikan yang ada dilingkungan sekolah selalu meningkatkan kemampuan dan tanggung jawab dengan memperhatikan kesejahteraan, dan rasa kebersamaan untuk mencapai produktifitas kerja yang sesuai dengan yang telah ditetapkan. Seperti yang telah dijelaskan di atas meengenai peran kepala sekolah diihat masi sangat kurang walaupun terlihat ada usaha dari kepala sekolah mengenai kedisiplinan ini namun masi banyak kekurangan yang perlu diperhatikan sebagai seorang kepala sekolah, yakni dari berbagai situasi dan kondisi. ${ }^{13}$

Dengan demikian Peran kepala sekolah yang diterapkan di MI Ma'rif Garongan Kulonprogo antara lain :

\section{Kepala sekolah sebagai perencana}

Beradasarkan hasil penelitian dan didukung oleh wawancara dengan kepala sekolah "peran kepala sekolah sebagai perencana untuk meningkatkan kedisiplinan guru dalam kehadiran mengajar agar dapat terwujud dengan baik perlu direncanakan terlebih dahulu karena Setiap kegiatan apapun namanya ada tahapan yang

\footnotetext{
${ }^{13}$ Ngalim Purwanto, Administrasi dan Supervisi Pendidikan, (Bandung : PT Remaja Rosdakarya, 2002), hlm. 6
}

harus dilakukan begitu pula dengan upaya kepala sekolah dalam meningkatkan kedisiplinan guru, dalam setiap kegiatan apapun namanya perencanaan. Adapun perencanaan yang telah disepekati bersama di MI Ma'arif garongan dalam meningkatkan kedisiplinan guru dalam kehadiran mengajar, kemudian memilih atau menentukan bagaimana cara-cara mencapai tujuan tersebut. Adapun perencanaan yang dilakukan oleh kepala sekolah antara lain dengan cara membuat program seperti sebagai berikut:

- Merencanakan peraturan disiplin kehadiran untuk disepakati bersama beserta sanksinya

- Merencanakan jadwal sosialisasi dan pembinaan kedisiplinan

Namun Terkadang dalam perencanaan tidak berjalan sesuai dengan apa yang diharapkan dikarenakan terjadi beberapa faktor karena guru di MI Ma'arif Garongan memiliki latar belakang keluarga yang berbeda-beda. ${ }^{14}$

\section{Kepala sebagai pelaksana}

Dalam menjalankan perannya kepala sekolah sudah menjalankannya dengan baik dengan selalu hadir disekolah tepat waktu dan menjadi orang yang pertama datang dan pulang selalu sesuai jam kantor, dan apabila ada kelas yang masih terisi oleh guru , kepala sekolah selalu mengambil alih bagian tersebut.. ${ }^{15}$

Berdasarkan hasil wawancara yang dilakukanm peneliti bersama kepala sekolah dalam menjalankan perannya kepala sekolah telah melaksanakan perannya sessuai dengan peraturan yang telah ditetapkan bersama melalui musyawarah. Dalam hal ini kepal sekolah telah menjadi panutan bagi guru lain dalam memberikan tauladan yang baik.

\section{Mengawasi hubungan antara anggota- anggota kelompok}

Berdasarkan hasil observasi dan diperkuat dengan wawancara yang telah dilakukan oleh peneliti peran kepala sekolah dalam

${ }^{14}$ Hasil wawancara dengan ( Ibu Lisdiyati, S.Pd.I) selaku kepala sekolah MI Ma'arif Garongan pada hari kamis, 7 Mei 2018 pukul 07.3 0 WIB

${ }^{15}$ Observasi pada tangga 4 Mei 2018 
mengawasi hubungan antara anggota-anggota telah terlaksana dengan baik. Namun ketegasan dalam mengambil sikap kepala sekolah masih jauh dari kata tegas, Artinya kepala sekolah belum berani mengambil sikap yang tegas sesuai perannya. Namun dalam hal memberi panutan kepala sekolah sudah menjalankan tugasnya sesuai dengan apa yang diharapkan dalam perencanaan ysng telah dibahas pada perencaan melalui musyawarah.

\section{Kepala sekolah mewakili kelompok}

Berdasarkan observasi yang diperoleh di lapangan dalan menjalankan perannya mewakili kelompok, kepala sekolah sudah menjalannya sesuai dengan apa yang telah diterapkan. Misalnya ketika guru kelas berhalangan untuk masuk sekolah, kepala sekolah selalu mengambil alih kelas yang kosong tersebut. Kepala sekolah dalam menjalankan perannya sebagai mewakili kelompok sudah terbilang sesuai dengan apa diharapkan, seperti datan tepat waktu dalam ha ini memberi contoh pada guru serta staf yang lain. Selalu mengambil alih mengisi jam kosong disaat kelas belum ada guru. Yang menjadi poin penting bagi kepala sekolah disini adalah bertindak tegas, untuk persoalan ini kepala sekolah sangat minim sekali.

\section{Bertindak sebagai pemberi ganjaran dan hukuman.}

"Berdasarkan hasil wawancara bersama kepala sekolah terkait dengan memberi teguran jika ada Bapak/Ibu ada yang melanggar kedisiplinan yang telah diterapkan sebagai kepala sekolah langkah pertama yang dilakukan adalah melalui pemberian teguran (peringatan), terus yang kedua jika diberi teguran juga tidak ada perubahan maka kepala sekolah mempunyai wewenang untuk melaporkan yang bersangkutan ke pengawas madrasah setelah itu pengawas madrasah yang menindaklanjuti ke kantor pusat." 16

${ }^{16}$ Hasil wawancara dengan ( Ibu Lisdiyati, S.Pd.I) selaku kepala sekolah MI Ma'arif Garongan pada hari kamis, 9 Mei 2018 pukul 07.30 WIB
Peraturan yang telah diterapkan sedemikian indah namun dalam prakteknya belum terlaksanakan. Sehingga dalam menjalankan perannya sebagai pemberi ganjaran/hukuman, disini belum terlihat ketegasan yang beliau tampilkan, mungkin dikarenakan faktor gender. MI Ma'rif dipimpin oleh seroang perempuan, kecendrungan sifat wanita selalu mengutamakan perasaan, sehingga kurang tegas dalam mengambil tindakan. Seperti kejadian yang terjadi berulang kali dilakukan oleh beberapa guru yang seringkali mengulangi kesalahan yang sama yang cendererung terus-menerus seperti datang jam kantor tidak sesuia dengan kesepakatan yang diterapkan, kelas kosong disaat jam pelajaran berlansung, meskipun hal tersebut tidak berlaku untuk semua kelas. Tetapi terjadi dikelas yang sama dan terjadi secara terus menerus. Namun sejauh penelitian berlangsung belum pernah ditemui langkah serius untuk mengambil tindakan atas kejadian yang berlansung tersebut. Peran kepala sekolah sebagai pemberi hukuman disini belum dijalankan sepenuhnya. ${ }^{17}$

\section{Kepala Sekolah bertindak sebagai wasit}

Berdasarkan hasil observasi dalam menjalankan perannya sebagai seorang kepala sekolah $70 \%$ sudah melaksankan sesuai dengan apa yang diharapkan, meskipun dalam menjalankan perannya kepal sekolah masih kurang dalam hal ketegasan memberi hukuman. Itu semua tidak terlepas dari factor-faktor yang terjadi sepeti factor genre. Ini menjadi factor paling mempengaruhi kepal sekolah dalam memberikan ketegasan sikap. Hal-hal seperti ini jika dibiarkan terus menerus akan berdampak pada pola kepemimpinan sekolah.

Faktor Penghambat Serta Solusi Kepala Sekolah dalam Mengatasi Hambatan dalam Menerapkan Kedisiplinan Guru di MI Ma'arif Garongan.

Faktor penghambat

Setiap individu pasti memiliki latar belakang kehidupan yang berbeda-

${ }^{17}$ Observasi pada tanggal 1April-2 juni 2018 
beda dalam menjalankan hidupnya. Setiap proses tidak terlepas dari faktor-faktor yang mempengaruhinya. Faktor-faktor tersebut ada yang mendukung namun ada yang menghambat. Namun dalam penelitian ini peneliti hanya akan membahas faktor penghambat serta solusi dalam mengatasinya.

Berdasarkan wawancara yang dilakukan peneliti bersama kepala sekolah dengan hasil sebagai berikut : "faktor yang mempengaruhi yang pertama terjadi dari bapak ibu guru (faktor keluarga) bisa datang dari anak, suami, istri serta orang tua. Semua itu bisa dimaklumi (diberi keringanan) dengan syarat tidak meninggalkan kewajiban sebagai seorang guru. Mengingat sistem pengajaran di MI Ma'arif sudah berlaku kurikukulum 2013 yang melibatkan guru kelas bukan guru mata pelajaran lagi." 18

Berdasarkan hasil wawancara dan observasi juga diketahui bahwa faktor yang mempengaruhi kedisiplinan terdiri dari faktor keadaan keluarga, keadaan sekolah, keadaan masyarakat. ${ }^{19}$

Peneliti melihat bahwa faktor yang menonjol dalam penelitian ini adalaha faktor keadaan keluarga, seperti yang sudah dipaparkan penulis sebelumnya keluarga merupakan sumber dari segala kehidupan. Keluarga terkadang menjadi sumber kenyamanan sebagian orang tapi tidak bagi mereka yang tidak menemukan kenyamanan. Keluarga merupakan lingkungan tempat beradaptasi pertama sebelum masyarakat. Apa yang terjadi dalam keluarga berdampak pada kehidupan sosial seseorang mengingat keluarga nnerupakan lingkungan pertama.

Peneliti melihat bahwa yang terjadi di MI Ma'arif Garongan Kulonprogo Kepala Sebagai seorang pemimpin dalam menerapkan kedisiplinan sudah mendekati sesuai dengan aturan yang telah diterappkan . sedangkan kedisiplinan guru sudah mendekati kata baik, hanya beberapa guru yang yang masih masih

\footnotetext{
${ }^{18}$ Hasil wawancara dengan ( Ibu Lisdiyati, S.Pd.I) selaku kepala sekolah MI Ma'arif Garongan pada hari kamis, 02 Juni 2018 pukul 07.30 WIB

${ }^{19}$ Dolet Unaradjan, Manajemen Disiplin, (Jakarta: Grasindo,2003), Hlm.27-32
}

kurang kesadarannya dalam menerapkan kedisiplinan individunya.

\section{Solusi dalam mengatasi}

Berdasarkan hasil wawancara yang dilakukan peneliti sebagai berikut:

"solusi saya sebagai kepala sekolah mengambil wewenang dengan cara musyawarah bersama, bagaimana baiknya supaya kita ini bersama-sama mencari jalan keluar dalam menjalankan atau melaksanakan tugas yang telah diembankan sehingga dapat berjalan sesuai apa yang telah kita rencankan. ${ }^{20}$

Dengan hasil wawancara diatas peneliti menyimpulkan bahwa di MI Ma'arif Garongan menerapkan solusi dalam mengatasi faktor penghambat dengan melakukan musyawarah bersama untuk untuk mencari jalan keluar sesaui dengan aturan sekolah yang berlaku tanpa harus memandang sebelah mata terhadap pihak yang menjadi titik persoalan. Mengingat tugas seorang guru atau tenaga pendidik, bukan hanya mengajar, tetapi memiliki tugas yang amat kompleks dalam membentuk karakter, kepribadiaan, prestasi, serta perilaku anak secara optimal, karena yang dihadapi adalah makhluk hidup, maka seorang guru harus mengikuti secara aktif perkembangan dari peserta didiknya, agar menjadi anak yang berkembang secara utuh, baik jasmani maupun rohaninya. Seorang guru belum dikatakan tugasnya berakhir, apabila seorang guru belum bisa mencapai keberhasilan yang optimal. Keberhasilan yang optimal, itu apabila bisa menghasilkan produk yang mumpuni. Maka tugas guru tidak mudah, seperti yang dibayangkan selama ini, sebenarnya memiliki tanggung jawab yang berat baik pada waktu anak sedang didik, sampai dia dikatakan sudah bisa mandiri secara fisik maupun psikisnya.

\section{KESIMPULAN}

Seorang kepala sekolah adalah motor penggerak keberhasilan tujuan sekolah, karena dia adalah pemimpin di lingkungannya. Kepala

\footnotetext{
${ }^{20}$ Hasil wawancara dengan ( Ibu Lisdiyati, S.Pd.I) selaku kepala sekolah MI Ma'arif Garongan pada hari kamis, 04 Juni 2018 pukul 08.30 WIB
} 
sekolah harus mampu menggerakkan dengan baik dengan usaha yang optimal sehingga tujuan organisasi yang dipimpinnya dapat tercapai dengan baik. Semua usaha kepala sekolah merupakan kemampuan seseorang kepala sekolah dalam mempengaruhi individu atau kelompok yang dipimpinya melalui suatu proses untuk mencapai tujuan organisasi.

Berdasarkan hasil penelitian, pembahasan serta analisis yang telah peneliti lakukan tentang peran kepala sekolah dalam menerapkan kedisiplinan guru di MI Ma'arif Garongan Kulonprogo, maka penulis dapat mengambil kesimpulan sebagai berikut :

Peran kepala sekolah dalam menerapkan kedisiplinan guru di MI Ma'arif Garongan Kulonprogo Yogyakarta menerapkan kedisplinan guru dengan kepala sekolah menjalankan peran kepala sekolah sebagai pelaksana, perencana, seorang ahli, pelindung, Pemegang tanggung jawab, sebagai pencipta, dan sebagai wasit. Memberikan dampak yang positif dilingkungan MI Ma'arif Garongan.

Faktor penghambat bagi kepala sekolah dalam menerapkan kedisiplinan guru di MI Ma'arif garongan Kulonprogo Yogyakarta yakni keadaan keluarga. keadaan keluarga menjadi faktor penghambat terbesar dalam menerapkan kedisiplinan guru di MI Ma'arif garongan Kulonprogo Yogyakarta. Solusi dalam mengatasi faktor penghambat adalah dengan melakukan musyawarah bersama serta melakukan evaluasi untuk mengatasi hambatan tersebut.

\section{DAFTAR PUSTAKA}

Abdul Munir, 2014. Menjadi Kepala Sekolah Efektif, Yogyakarta: Ar-Ruzz Media.

Abdurrahmat Fathoni, 2006. Manajemen Sumber Daya Manusia, Jakarta : Rineka Cipta.

Dolet Unaradjan, 2003. Manajemen Disiplin, Jakarta: Grasindo

Enco Mulyasa, 2011. Menjadi Kepala Sekolah Profesional, Bandung: PT Remaja Rosda Karya.

Euis Karwati dan Donni Juni Priansa, 20013. Kinerja dan Profesionalisme Kepala Sekolah, Bandung: Alfabeta.

Husain Usman, 1996. Metode penlitian sosial, Jakarta : Bumi Aksara.

Lembaga Ketahan Nasional, 1997. Disiplin Nasional, Jakarta: Balai Pustaka.

Lexi J.Moleong,M.A, 2010. Metodelogi penelitian kualitatif, Bandung: PT Remaja Rosdakarya.

Ngalim Purwanto, 2002. Administrasi dan Supervisi Pendidikan, Bandung: PT Remaja Rosdakarya

Ratna, Sri dan Murtini, 2006. Dinamika Kelompok, Jakarta: LAN.

Sugiyono, 2009.Metodelogi Kuantitatif Kualitatif dan $R \& D$, Bandung: Alfabeta.

Wahjosumidjo, 1995. Kepemimpinan Kepala Sekolah. Jakarta:Rajawali Pers. 